\title{
Analisa Horizontal Handover Terhadap QoS Layanan Streaming Multimedia E-Learning Pada Jaringan WLAN 802.11
}

\author{
I Made Oka Widyantara, Bagus Dwi Cahyono, dan Widyadi Setiawan
}

\begin{abstract}
In this globalization era, the state of the user who no longer occupies in a single place, but always moving, it is necessary to continuity of communication that will cause a handover. This paper intends to analyze the effect of 802.11 WLAN horizontal handover to the QoS of streaming e-learning. Methods of data collection process using the Cisco 3500 series access point that supports handover with existing network systems, ad-hoc network and type of hard handover. The results of the data analysis showed that the handover process is able to improve the QoS by gradually restored gradually, to get back to normal QoS
\end{abstract}

Index Terms - Horizontal handover, WLAN 802.11, QoS, Multimedia Streaming, E-Learning

\begin{abstract}
Abstrak - Dalam zaman globalisasi seperti saat ini, keadaan pengguna yang tidak lagi menempati pada suatu tempat saja, namun selalu berpindah-pindah, diperlukan adanya kontinyuitas komunikasi sehingga akan menimbulkan suatu handover. Paper ini bermaksud menganalisis pengaruh handover WLAN 802.11 terhadap QoS streaming e-learning. Metode proses pengambilan data menggunakan perangkat Cisco 3500 series access point yang mendukung layanan handover dengan sistem jaringan existing, jaringan ad-hoc dan type hard handover. Hasil analisa data menunjukkan bahwa proses handover ini mampu memperbaiki QoS dengan berangsur-angsur dipulihkan secara bertahap, hingga mendapatkan QoS yang kembali normal
\end{abstract}

Kata kunci- Horizontal handover, WLAN 802.11, QoS, Multimedia Streaming, E-Learning

\section{Pendahuluan}

$\mathrm{P}$ ADA jaringan Wireless Local Area Network (WLAN) / Institute of Electrical and Electronics Engineers (IEEE) 802.11 adalah suatu jaringan area local tanpa kabel dimana media transmisinya dapat berupa frekuensi radio (RF) dan infrared (IR). WLAN memiliki keunggulan pada sisi mobilitas dan produktivitas tinggi. WLAN memungkinkan user untuk mengakses secara realtime, user dapat menggunakan jaringan dimanapun selama masih berada dalam coverage area WLAN.

I Made Oka Widyantara adalah dengan Lab. Sistem Telekomunikasi, Jurusan Teknik Elektro, Fakultas Teknik, Universitas Udayana (e-mail: oka.widyantara@unud.ac.id).

Bagus Dwi Cahyono adalah dengan Jurusan Teknik Elektro, Fakultas Teknik, Universitas Udayana (e-mail: utami.wedanti@ymail.com).

Widyadi Setiawan adalah dengan Jurusan Teknik Elektro, Fakultas Teknik, Universitas Udayana (e-mail: alit_bbc@yahoo.com).
Namun jika user berpindah-pindah tempat, maka hanya mendapatkan jangkauan yang relative kecil, hal ini dapat menyebabkan perangkat mobile akan mengalami handover.

Handover adalah proses dimana mobile node (MN) berpindah dari satu jaringan access point (AP) ke jaringan AP yang lain (foreign network). Secara umum handover yang hanya mengalami perubahan pada link layer (layer 2 OSI) tanpa mengubah alamat IP dinamakan horizontal handover. Misalnya ketika MN berpindah pada AP LAN yang dilayani oleh IP access router yang sama. Pada terminology 802.11 kedua AP berada pada Extend Sevice Set (ESS) yang sama [1].

Aplikasi streaming multimedia memiliki karakteristik quality of service (QoS) yang tidak toleran terhadap delay. Maka ketika diimplementasikan pada jaringan 802.11, jaringan harus menjamin konekvitas dalam proses handover. Pada jaringan 802.11, proses handover dibagi menjadi tiga proses utama, yaitu (i) probing (scaning), (ii) reauthentication, dan (iii) re-association. Selaras dengan [2][3] prosedur handover pada WLAN 802.11 memakan waktu sampai ratusan milidetik, dan hampir $90 \%$ delay handover terjadi pada proses pencarian AP baru. Latency handover yang besar akan menghasilkan gap tampilan dan kualitas layanan dari aplikasi streaming multimedia. Dengan kata lain, asosiasi sebuah MN dengan AP hanya didasarkan pada pengukuran Received Signal Strength Indicator (RSSI) dari seluruh AP tetangga. MN akan keluar dari keanggotaan pada sebuah AP ketika nilai RSSI dibawah dari nilai threshold yang telah ditetapkan.

Saat ini terdapat banyak penelitian difokuskan pada analisis handover untuk meningkatkan kualitas layanan multimedia, diantaranya adalah memperbaiki metode handover pada jaringan WLAN 802.11[4]-[8]. Mekanisme yang digunakan adalah memperbaiki mekanisme handover pada lapisan Medium Access Control (MAC) pada jaringan 802.11 dengan prosedur Prevent Scan Handoff Procedure (PSHP) yang dapat menurunkan delay pada proses probing.

Berdasarkan pemaparan diatas, maka perbaikan mekanisme handover dapat meningkatkan QoS layanan streaming multimedia. Akan tetapi mekanisme kinerja QoS layanan streaming multimedia akibat penerapan mekanisme QoS belum dilakukan pada kondisi jaringan yang sudah terpasang. Maka, paper ini bermasud untuk mengevaluasi handover intra-cell (horizontal handover) terhadap QoS layanan 
streaming multimedia. Evaluasi dilakukan pada layanan streaming multimedia e-learning di jaringan Universitas Udayana.

Selanjutnya, paper ini diorganisasikan sebagai berikut; bab I memaparkan tentang latar belakang analisis horizontal handover terhadap QoS layanan streaming multimedia eleaning, bab II memaparkan tentang mekanisme handover pada jaringan WLAN 802.11, bab III memaparkan tentang rancangan simulasi, bab IV memaparkan tentang evaluasi QoS layanan, dan bab V adalah kesimpulan dari paper ini.

\section{MEKANISME HANDOVER PADA JARINGAN WLAN 802.11}

Kebutuhan akan mobilitas yang semakin luas jangkaunnya, menimbulkan masalah pada coverage area AP yang terbatas. Masalah ini diatasi dengan memasang beberapa AP pada titiktitik tertentu dengan tujuan menambah jangkauan akses terhadap perangkat wireless. Dikarenakan suatu perangkat wireless hanya dapat terhubung dengan sebuah AP maka diperlukan perpindahan koneksi antara suatu perangkat wireless dengan AP baru yang berada diwilayah jangkauannya. Proses inilah yang dikenal dengan istilah handover. Dalam implementasinya, prosedur handover dibedakan pada pada hirarki konektivitasnya, yaitu fast handover, horizontal handover, dan vertical handover.

\section{A. Fast Handover}

Perangkat client hanya akan dapat terhubung ke satu AP walaupun client berpindah kemanapun. Perangkat client secara otomatis akan melakukan scanning memilih AP mana yang lebih baik dari sekian banyak AP yang tersedia. Handover akan memaksa client untuk mengganti koneksi AP ke koneksi yang lebih baik jika tersedia.

\section{B. Horizontal Handover}

Seperti ditunjukan pada Gambar 1, horizontal handover mengalami perubahan hanya pada link layer (layer 2 OSI), sehingga tidak terjadi perubahan alamat IP. Contohnya adalah ketika MN berpindah pada access point wireless LAN yang dilayani oleh IP access router yang sama. Pada terminology 802.11 kedua access point berada pada Extend Sevice Set (ESS) yang sama. Handover yang hanya mengalami perubahan pada link layer (layer 2 OSI) tanpa mengubah alamat IP.

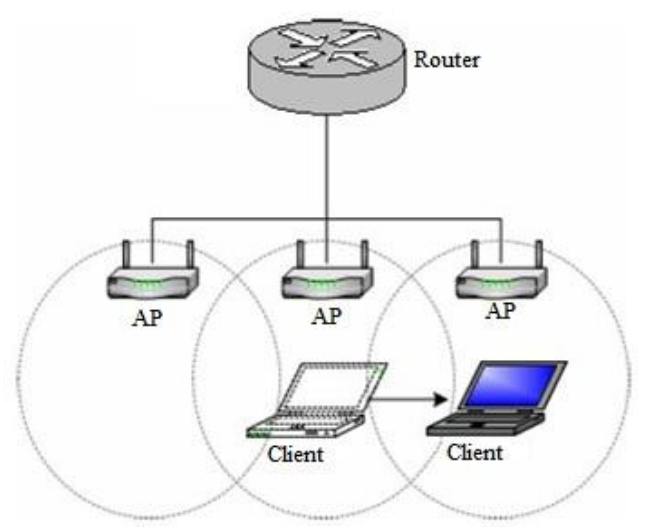

Gambar 1. Horizontal handover

\section{Vertical Handover}

Handover yang terjadi ketika MN berpindah diantara access point yang berbeda ESS dan dilayani oleh access router yang berbeda dinamakan Vertical Handover, seperti yang digambarkan pada Gambar 2. Vertical handover dapat terjadi diantara provider yang sama maupun provider yang berbeda.

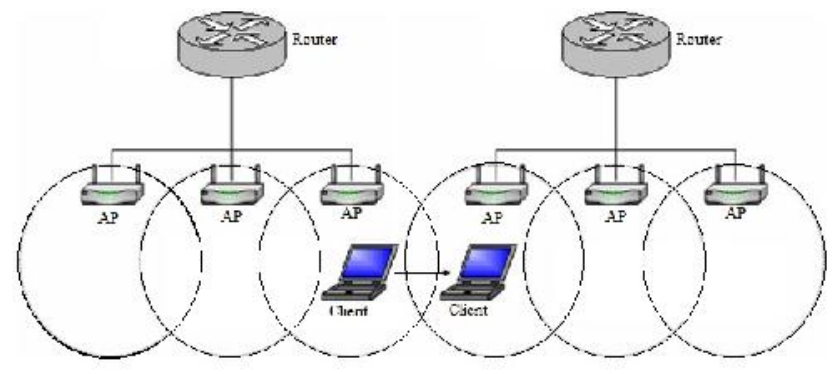

Gambar 2. Vertical Handover

\section{IEEE 802.11 Skenario Handover}

IEEE 802.11 mempunyai tiga perbedaan skenario dalam perpindahan handover, seperti ditunjukan pada Gambar 3:

1. Tanpa Transisi : Dalam type ini, dua subclass yang biasanya dapat dibedakan dalam:

a. Pergerakan Statik.

b. Pergerakan local client didalam satu jaringan Basic Service Set (BSS) / area acess point (AP) yang masih berada dalam satu network.

Gambar 3. Skenario Handover

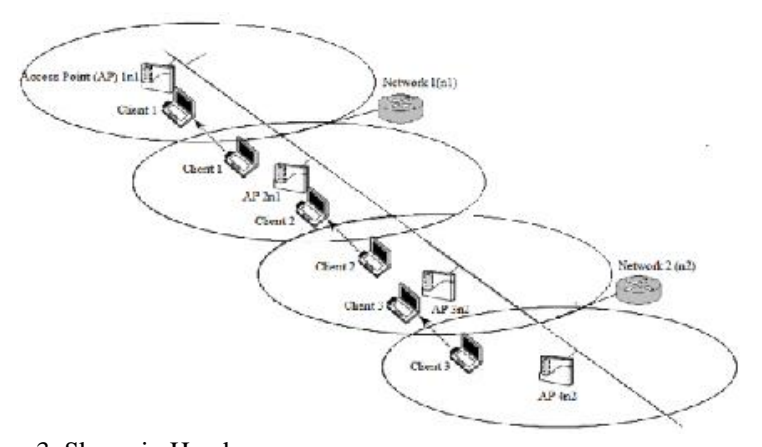

2. Transisi acess point : Type ini merupakan pergerakan stasiun (client) dari satu access point ke lainnya didalam extended service set (ESS)

3. Transisi ESS : Pergerakan client dari BSS dalam satu ESS ke BSS dalam ESS yang berbeda. Biasanya jaringan WLAN berada didalam ESS dan di subnet IP.

\section{E. Multimedia E-learning}

Kombinasi teknologi telekomunikasi dan internet memungkinkan pengembangan sistem e-learning yang pada sisi klien memanfaatkan divais begerak, berinteraksi dengan sisi server.

Penggunaan teknologi informasi dan komunikasi di dalam dunia pendidikan terus berkembang dalam berbagai strategi dan pola, yang pada dasarnya dapat dikelompokkan ke dalam sistem e-learning sebagai bentuk pembelajaran yang memanfaatkan perangkat elektronik dan media digital, maupun mobile learning ( $m$-learning) sebagai bentuk 
pembelajaran yang khusus memanfaatkan perangkat dan teknologi komunikasi bergerak.

Tingkat perkembangan perangkat bergerak yang sangat tinggi, tingkat penggunaan yang relatif mudah, dan harga perangkat yang semakin terjangkau, dibanding perangkat komputer personal, merupakan faktor pendorong yang semakin memperluas kesempatan penggunaan atau penerapan mobile learning sebagai sebuah kecenderungan baru dalam belajar, yang membentuk paradigma pembelajaran yang dapat dilakukan dimanapun dan kapanpun.

\section{F. Quality of Service (Qos)}

Performansi mengacu ke tingkat kecepatan dan keandalan penyampaian berbagai jenis beban data di dalam suatu komunikasi. Performansi merupakan kumpulan dari beberapa parameter besaran teknis, yaitu :

- Waktu Tunda (Delay) adalah waktu yang diperlukan oleh suatu paket data dari source node hingga mencapai destination node. Delay dalam suatu jaringan juga merupakan unjuk kerja yang dapat dijadikan acuan dalam menilai kemampuan dan kualitas pengiriman data. Akibat dari delay, data yang kita terima akan mengalami keterlambatan waktu datang sehingga hal ini menyebabkan kita menunggu sejenak data tersebut sampai pada tujuan.Delay akan sangat kita rasakan ketika kita melakukan pengiriman paket data yang bersifat realtime. [6]

- Waktu Tanggapan (Response time) adalah rentang waktu antara seorang user memasukkan perintah ke sistem hingga sistem memberikan jawaban dengan menampilkannya ke display (monitor). Dalam pengukuran Response Time, waktu yang diukur adalah dari user mulai mengklik tombol load pada web browser hingga halaman situs selesai dibuka (downloaded) seluruhnya. [7]

- Throughput adalah besar ukuran data yang berhasil diterima pada proses transmisi data dalam rentang waktu tertentu. Throughput walau pun memiliki satuan dan rumus yang sama dengan bandwidth, tetapi Throughput lebih pada menggambarkan bandwidth yang sebenarnya (aktual) pada suatu waktu tertentu dan pada kondisi dan jaringan internet tertentu yang digunakan untuk mendownload suatu file dengan ukuran tertentu. [8]

\section{RANCANGAN IMPLEMENTASI HORIZONTAL HANDOVER PADA JARINGAN WLAN 802.11}

Analisis pengaruh handover WLAN 802.11 terhadap QoS akan diujikan pada layanan multimedia e-learning. Layanan multimedia e-learning menggunakan video sebagai media bantu dalam pembelajaran.

Kualitas horizontal handover yang ditinjau berdasarkan pada waktu tunda, waktu tanggapan, dan throughput. Nilai Qos diperoleh dari "server" pertama kali mengirimkan paketnya, yaitu ketika dilakukannya request pemutaran video streaming mulai detik pertama, hingga pengiriman paket yang terakhir yaitu saat video tersebut selesai sehingga video tersebut dapat ditampilkan seluruhnya pada layanan Elearning

\section{A. Skenario I}

Seperti ditunjukan pada Gambar 4, skenario ini bertujuan untuk mengetahui pengaruh horizontal handover jaringan existing WLAN 802.11. Jaringan existing adalah jaringan WLAN 802.11 yang telah terpasang/ada sebelumnya. Detail

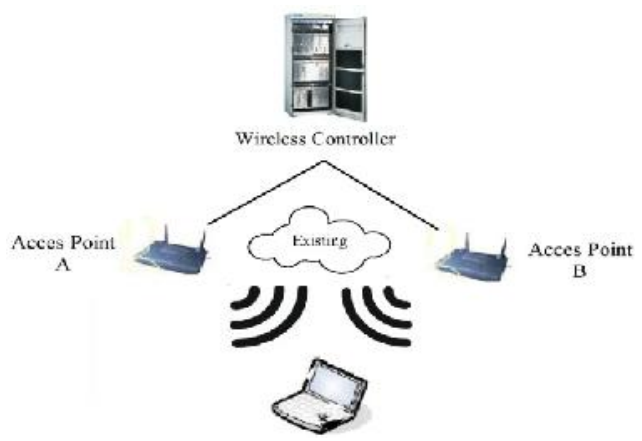

Gambar 4. Rancangan Skenario I

\section{B. Skenario II}

Pada skenario ini bertujuan untuk mengetahui pengaruh Horizontal handover jaringan ad-hoc WLAN 802.11. Jaringan yang digunakan pada pengujian ini dibuatkan jaringan access point WLAN yang baru. Seperti pada Gambar 5, client bergerak dari access point A berpindah ke access point B dengan melakukan streaming video pada layanan E-learning.

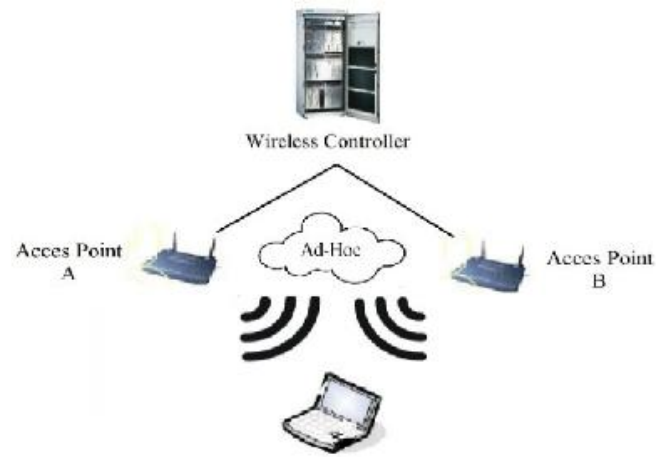

Gambar 5. Rancangan Skenario II

\section{Skenario III}

Pada skenario ini bertujuan untuk mengetahui pengaruh horizontal handover jaringan ad-hoc WLAN 802.11. Jaringan yang digunakan pada pengujian ini dibuatkan jaringan access point WLAN yang baru.

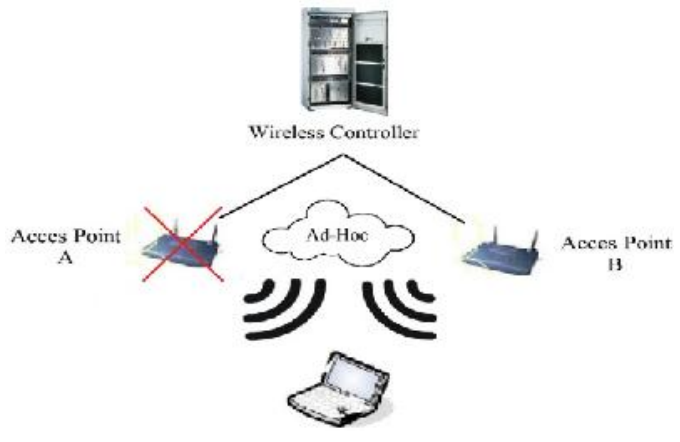

Gambar 6. Rancangan Skenario II 


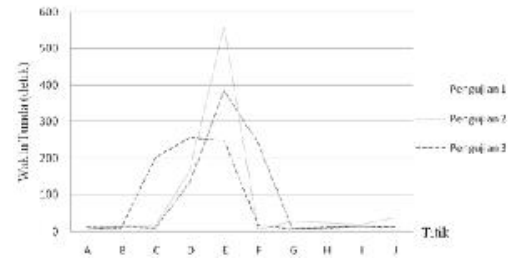

(a)

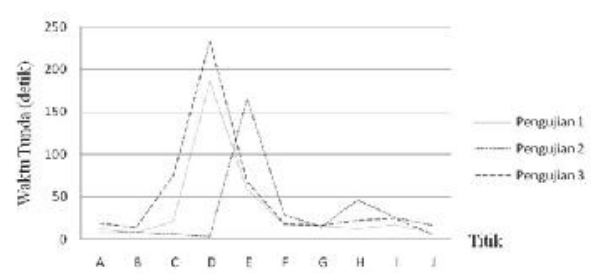

(b)

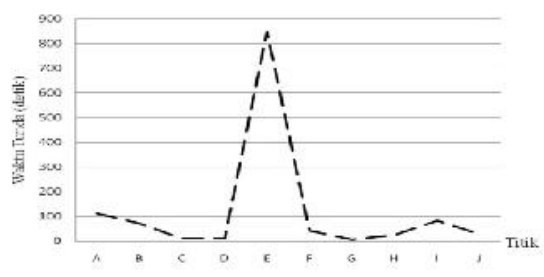

(c)

Gambar 7. Waktu tunda proses hozontal handover terhadap layanan streaming multimedia e-learning pada jaringan WLAN 802.11, (a) Skenario di jaringan eksisting, (b) Skenario di jaringan adhoc tipe I, dan (c) Skenario di jaringan sdhoc tipe II.

Seperti ditunjukan pada Gambar 6, client bergerak dari access point $\mathrm{A}$ berpindah ke access point $\mathrm{B}$ dengan melakukan streaming video pada layanan E-learning. Ketika client masih berada diantara ruang lingkup access point $\mathrm{A}$, access point $\mathrm{A}$ tersebut dimatikan, sehingga hal ini akan memaksa client berpindah menggunakan layanan ke access point $\mathrm{B}$ dengan otomatis. Proses handover dengan cara ini termasuk type hard handover.

\section{HASIl DAN PEMBAHASAN}

Pengujian untuk analasis horizontal handover terhadap QoS layanan streaming multimedia e-learning dilakukan dengan mekanisme yang sama untuk seluruh skenario yang telah ditetapkan. Menggunakan perangkat AP Cisco 3500, setiap pengujian dimulai dari titik A (access point lantai 2) berpindah titik per titik hingga sampai titik $\mathbf{J}$ (access point lantai 1). Setelah melakukan pengujian pertama, langsung dilakukan pengujian yang berikutnya, diulang lagi mulai dari titik A sampai titik $\mathbf{J}$ dengan memutar konten video yang sama. Selanjutnya, evaluasi QoS layanan streaming multimediae-learning dianalisa berdasarkan tiga parameter, yaitu waktu tunda, waktu tanggapan, dan throughput. Hasil pengukuran diperoleh dengan tool Wireshark.

\section{A. Evaluasi QoS Waktu tunda}

Hasil data pengujian waktu tunda ini bertujuan untuk mengetahui jumlah waktu yang dibutuhkan oleh suatu paket data dari source node hingga mencapai destination node yang terjadi pada pengiriman paket streaming e-learning. Akibat dari waktu tunda data yang diterima akan mengalami keterlambatan waktu datang sehingga hal ini menyebabkan menunggu sejenak hingga data tersebut sampai pada tujuan. Pada proses ini, waktu tunda yang rendah merupakan salah satu bukti bahwa kualitas horizontal handover dari layanan jaringan existing yang digunakan bekerja dengan baik.

Perbedaan waktu tunda dengan waktu tanggapan yang mendasar adalah waktu tunda mengukur tiap-tiap paket yang dikirimkan dari sumber menuju ke tujuannya, sedangkan waktu tanggapan me merupakan penghitungan seluruh paket yang dikirim hingga paket yang terakhir.

Seperti ditunjukan pada Gambar 7, secara umum terlihat bahwa pada semua skenario implementasi horizontal, nilai waktu tunda terbesar terjadi pada titik C, D dan E, yang merupakan batas tepi daerah cakupan AP. Pada jaringan eksisting proses horizontal handover berfluktuasi diantara 3 kali waktu pengujian, dimana waktu tunda terbesar terjadi sampai 558 milidetik. Hal ini disebabkan jumlah traffik yang dilayani oleh AP adalah dinamis. Berbeda dengan skenario II, fluktuasi waktu tunda poses horizontal handover tidak terlalu besar. Hal ini disebabkan karena skenario yang dibangun adalah pada jaringan testbed. Delay terbesar proses horizontal terjadi pada skenario jaringan II, dimana posisi MN yang masih dalam area pelayanan harus tidak mendapat koneksi karena APnya dipaksa dimatikan. Pada skenario ini, proses waktu horizontal handover terbesar terjadi pada proses pencarian AP baru, dengan waktu tunda terbesar sampai 847,4 milidetik.

\section{B. Evaluasi QoS Waktu Tanggap}

Perbedaan waktu tanggap dengan waktu tunda yang mendasar adalah berada pada kapan perhitungan waktunya dimulai. Jika waktu tanggapan merupakan jumlah waktu total paket streaming ketika pengiriman paket yang pertama sampai pengiriman paket yang terakhir kalinya. Maka, waktu tunda adalah jumlah waktu yang didapat ketika pengiriman suatu paket data dari sumber sampai data yang dikirimkan tersebut diterima oleh node yang dituju. Dengan kata lain, waktu tanggap merupakan penghitungan seluruh paket yang yang dikirim hingga paket yang terakhir, sedangkan waktu tunda mengukur per-paket yang dikirimkan dari sumber menuju ke tujuannya.

Seperti ditunjukan pada Gambar 8, waktu tanggap dari implementasi horizontal handover pada jaringan WLAN 802.11 untuk layanan streaming multimedia e-learning bervariasi di setiap skenario jaringan yang ditetapkan, bergantung posisi $\mathrm{MN}$ dalam sebuah $\mathrm{AP}$, dan jumlah $\mathrm{MN}$ dalam terlayani dalam AP tersebut. Proses handover akan terjadi ketika $\mathrm{MN}$ memperolej nilai waktu tanggap yang tinggi. Berdasarkan waktu tunda di Gambar 7, maka implementasi horizontal handover mampu memperbaiki QoS dengan berangsur-angsur dipulihkan secara bertahap, hingga mendapatkan QoS waktu tanggapan yang kembali normal

\section{Evaluasi QoS Throughput}

Nilai throughput diperoleh dengan membagi jumlah paket yang diterima dengan jumlah waktu pengamatan. Pada proses ini, nilai throughput yang tinggi merupakan salah satu bukti bahwa kualitas horizontal handover dari layanan jaringan bekerja dengan baik.

Gambar 9 menunjukkan nilai throughput dari hasil horizontal handover untuk layanan streaming multimedia elearning pada jaringan WLAN 802.11. Terlihat bahwa nilai throughput terendah berada pada D dan E. Hasil ini adalah sesuai bahwa ketika waktu tunda besar maka nilai throughput 


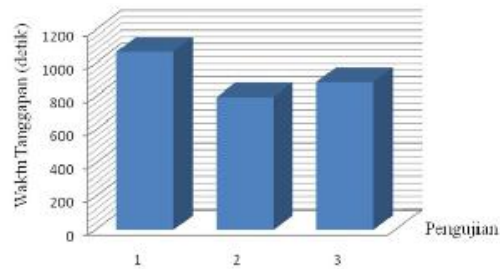

(a)

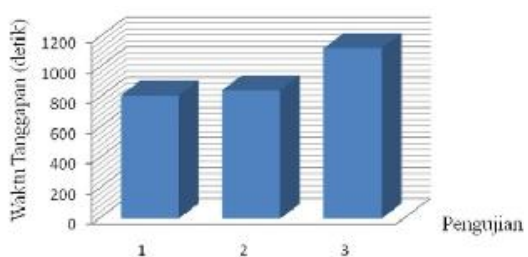

(b)

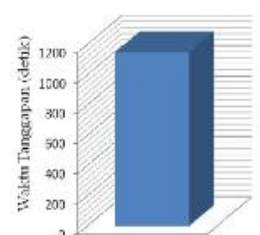

(c)

Gambar 8. Grafik nilai waktu tanggap proses hozontal handover terhadap layanan streaming multimedia e-learning pada jaringan WLAN 802.11, (a) Skenario di jaringan eksisting, (b) Skenario di jaringan adhoc tipe I, dan (c) Skenario di jaringan sdhoc tipe II.

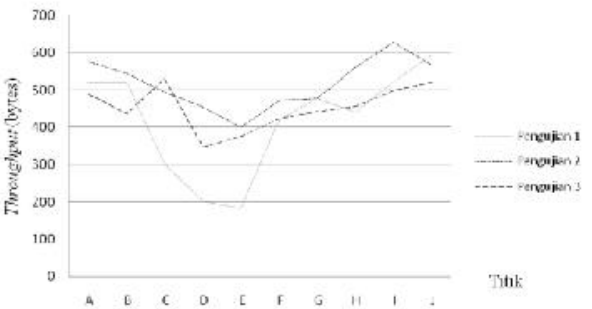

(a)

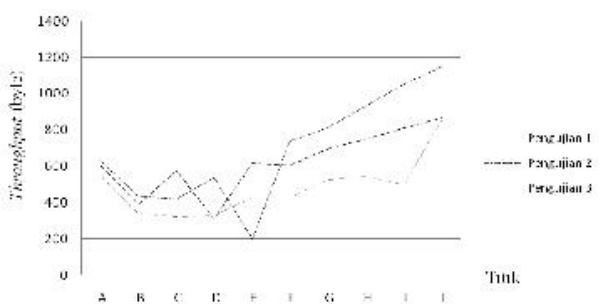

(b)

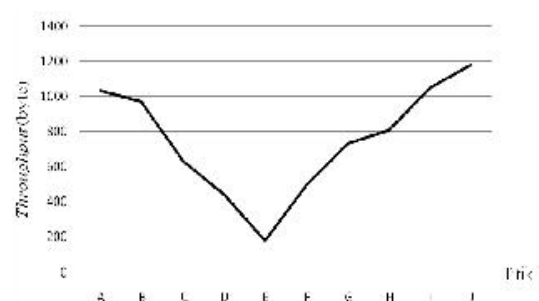

(c)

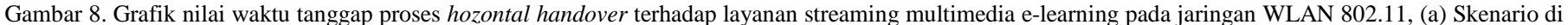
jaringan eksisting, (b) Skenario di jaringan adhoc tipe I, dan (c) Skenario di jaringan sdhoc tipe II.

menjadi rendah, dan merupakan area dimana MN harus melakukan proses handover. Selanjutnya, proses horizontal handover ini mampu memperbaiki QoS dengan berangsurangsur dipulihkan secara bertahap, hingga mendapatkan QoS throughput yang kembali normal.

\section{KeSIMPULAN}

Paper ini telah memaparkan model VSS berbasis Web-SIG untuk meningkatkan efisiensi visualiasi streaming video IP Camera. Model VSS yang diusulkan menambahkan fitur-fitur layanan seperti marker cluster atau grouping marker, kemudian fitur untuk menampilkan live streaming IP Camera dan yang terakhir adalah fitur geometry untuk memperoleh koordinat pemetaan IP Camera. Hasil uji coba yang dilakukan dengan menggunakan analisa usability software, yaitu tahap analisa terhadap tingkat kemudahan, serta pemahaman pengguna baik itu pengguna umum yaitu masyarakat ataupun admin, dalam menggunakan aplikasi yang telah dibuat, menunjukan bahwa fitur-fitur dalam Google Map API tersebut dapat berjalan dengan baik pada aplikasi yang berjalan di Web

\section{REFERENCES}

[1] Surendro , Krisnha Prasetyo, Menentukan Optimasi Routing dengan Pengaturan Route Advertisement pada Jaringan Mobile IPV6. Magister Teknik Elektro, Universitas Mercu Buana, 2010

[2] A. Mishra, Min ho Shin, W. Arbaugh, "An empirical analysis of the IEEE 802.11 MAC layer handoff process," ACM SIGCOMM Computer Communication Review, vol. 33: 93-102, April 2003.

[3] G. Bianchi, L. Fratta, and M. Oliveri, "Performance Evaluation and Enhancement of the CSMA/CA MAC Protocol for 802.11 Wireless LANS," Proceedings of the 7th International Symposium on Personal, Indoor and Mobile Radio Communications (PIMRC), vol. 2, pp. $392-$ 396, 1996.

[4] Ahmed Riadh Rebai, dan Saïd Hanafi," An Adaptive MultimediaOriented Handoff Scheme For Ieee 802.11 Wlans", International Journal of Wireless \& Mobile Networks (IJWMN) Vol. 3, No. 1, 2011, hal. 151170 .

[5] Sunggeun Jin, dan Sunghyun Choi,"A Seamless Handoff with Multiple Radios in IEEE 802.11 WLANs", IEEE Transactions on Vehicular Technology, Vol. 63, No. 3, 2013, hal. 1408-1418.
[6] Seungmin Kim, Myungchul Kim, Ben Lee, Yohaan Yoon, Sangyup Han, Sungwon Kang,"LOHAS: LOad balancing with fast Handoff Scheme on smartphones over IEEE 802.11 WLANs", Proceedings of the 11th ACM international symposium on Mobility management and wireless access, hal. 147-154

[7] M. Raghavan, A. Mukherjee, H. Liu, Q.A. Zeng, and D. P. Agrawal, "Improvement in QoS for Multimedia Traffic in Wireless LANs during Handoff," Proceedings of the 2005 International Conference on Wireless Networks (ICWN'05), Las Vegas, USA, pp. 251-257, Jun 27-30, 2005.

[8] H. Velayos and G. Karlsson, "Techniques to Reduce IEEE 802.11b MAC Layer Handover Time," in Proc. IEEE ICC 2004, vol. 7, pp. 3844-3848, June 2004.

[9] Saputra, IGA Apriliana, Analisisi QoS Media Independent Handover Antara Jaringan WLAN 802.11b dan WIMAX 802.16e. Jurusan Teknik Elektro Fakultas Teknik Universitas Udayana, 2011.

[10] Anand R.P., Neeli R.P., "802.11 WLANs and IP Networking security, QoS, and mobility", universal personal communications, London, 2005.

[11] Mahendra, N. A. Unjuk Kerja Streaming Video LAN pada Jaringan TCP/IP. Denpasar: Universitas Udayana, 2009.

[12] Stallings, W., "Computer Networking with Internet Protocols and Technology", Prentice Hall, New Jersey, 2004. 